\title{
Anglican Attitudes: Some Recent Writings on English Religious History, from the Reformation to the Civil War
}

\author{
Nicholas Tyacke
}

It remains a commonplace that what historians write bears some relation to their own time and particular angle of vision. Less often remarked, however, is the tendency for historical interpretations to acquire lives of their own, at least partly independent of the original circumstances that produced them, and to enter as it were the intellectual bloodstream of subsequent generations. A good illustration of this latter proposition is afforded by the history of the English Church. For, since at least the seventeenth century, the very radicalism of the Reformation has proved a continuing source of embarrassment to a section of Church of England opinion; rather than frankly admit their own dissent from the views of many of the Tudor founding fathers, they have regularly sought to rewrite the past in the light of the present. This conservative vision has come to be expressed in terms of a socalled via media, which is deemed to have characterized the English or "Anglican" way of religious reform.'

Until quite recently, the historiography was heavily influenced by these same Anglican insiders, other historians being prepared largely

Nicholas Tyacke is reader in history at University College London. He wishes to thank the following for commenting on a draft version of this article: Kenneth Fincham, Peter Lake, Diarmaid MacCulloch, and Fred Trott.

The works discussed in this article are G. Bernard, "The Church of England, c. 1529-c.1642," History 75 (1990): 183-206; S. Lambert, "Richard Montagu, Arminianism and Censorship," Past and Present, no. 124 (1989): 38-42; P. White, Predestination, Policy and Polemic: Conflict and Consensus in the English Church from the Reformation to the Civil War (Cambridge, 1992); J. Davies, The Caroline Captivity of the Church: Charles I and the Remoulding of Anglicanism (Oxford, 1992); and K. Sharpe, The Personal Rule of Charles I (New Haven, Conn., 1992).

${ }^{1}$ For a related argument, see D. MacCulloch, "The Myth of the English Reformation," Journal of British Studies 30 (January 1991): 1-19.

Journal of British Studies 35 (April 1996): 139-167

(c) 1996 by The North American Conference on British Studies.

All rights reserved. 0021-9371/96/3502-0001\$01.00 
to take on trust their claims-especially as regards theological change. Moreover, willingness to follow what is in effect a party line has now received powerful reinforcement from certain revisionist historians, who discern a congruence between the alleged moderation of Anglicanism and their own commitment to a consensual model of English politics in the decades before the Civil War. The old idea of the English Church as epitomizing a mean between the extremes of protestantism and catholicism is once more being pressed into service. Thus a new historiographical alliance has been created, between those concerned primarily to defend a particular reading of English religious history and others who emphasize the play of the contingent and unforeseen in explaining the crisis of 1640-42. Both these components are to some extent present in the wide-ranging article by George Bernard, published in the journal History during $1990 .^{2}$

At one level Bernard provides a classic, if rather exaggerated, example of old-style Anglican apologetic. Ostensibly writing about the English Church from ca. 1529 to ca. 1642, he nonetheless omits the crucial reign of Edward VI; conversely, no real distinction is drawn between religious developments under Henry VIII and later. Yet England became a protestant country at the official level only after the death of Henry VIII in 1547, moving thereafter fairly rapidly toward a Reformed position-influenced especially by the Continental theologians Martin Bucer and Peter Martyr, who were installed at Cambridge and Oxford, respectively. The liturgies and other formularies produced during the years 1547-53 mark a clear break with what had gone before, despite some continuity of personnel-notably, Archbishop Thomas Cranmer. Furthermore, the officially sponsored iconoclasm from cathedral down to parish level can have left people in little doubt that they were living through a time of drastic change. After the brief Marian restoration of catholicism, it was essentially the Edwardian Church which came back under Elizabeth in $1558 .{ }^{3}$ Bernard, however, like his historiographical forbears, proceeds to read off the Elizabethan settlement of religion in terms of its purported Henrician antecedents. At the same time, he invokes the notion of a "monarchical church," as serving to define the nature of the English Reformation. From this point of view, it was the jurisdictional break with Rome and not the

${ }^{2}$ G. W. Bernard, "The Church of England, c.1529-c.1642," History 75 (1990): 183-206. Bernard, like his colleague Kevin Sharpe, would appear to be attracted by an "Anglican" version of religious events primarily because of its innately revisionist thrust: see below, pp. 162-66.

${ }^{3}$ D. MacCulloch, The Later Reformation in England, 1547-1603 (Basingstoke, 1990); M. Aston, England's Iconoclasts, vol. 1, Laws against Images (Oxford, 1988), esp. chap. 6 . 
ensuing religious changes that mattered. The priorities of England's monarchical church were political stability rather than protestantism and, hence, what Bernard sees as recurring attempts to balance competing religious interests. We are in fact presented here with a politically driven concept of the Anglican middle way, but one which appears to depend on abolishing protestantism from the historical record.

There is too an underlying confusion, between the obvious desire of any regime to promote stability and the particular brand of Christianity obtaining in a given part of Europe from the sixteenth century onward. Bernard's main purpose, however, is to argue against the proposition that the English Church went through a Calvinist phase. The implication is that given the political imperatives of the monarchical church any such development was logically impossible. Nevertheless, historical reality has a way of defying the strict rules of logic, all the more so when the initial premise is in doubt. Bernard complains that those who have argued for a period of Calvinist dominance in the English Church begin their accounts "in medias res"- that is to say, the $1590 \mathrm{~s}$. Let us then take up his challenge and return ad fontes. Elizabethan doctrinal developments, as we have already indicated, must be understood in terms of an Edwardian legacy. While much is often made of the fact that Elizabeth's first archbishop of Canterbury, Matthew Parker, was uncontaminated by Marian exile, it is conveniently forgotten that he had been the Cambridge intimate of Bucer. As early as 1536, in a work dedicated to Cranmer, Bucer had expounded predestination and the theology of grace more generally along lines later to be called Calvinist. In his lectures as regius professor of divinity, at Edwardian Cambridge, Bucer reiterated this doctrine. Meanwhile at Edwardian Oxford, also as regius professor, Martyr can be found lecturing in similar vein. ${ }^{4}$ Again, the famous Elizabethan ThirtyNine Articles are a revised version of the Edwardian Forty-Two Articles of 1553. In the latter context, what is noteworthy is not their skirting around the doctrine of reprobation-God's "sentence"-but that unconditional predestination has a long article devoted entirely to it at so early a date. ${ }^{5}$ While the teaching of Bucer and Martyr exercised no monopoly among English protestants, the indications are that it was becoming increasingly influential by the death of Edward VI.

${ }^{4}$ Bernard, p. 184; M. Bucer, Metaphrases et Enarrationes Perpetuae Epistolarum D. Pauli Apostoli . . . Tomus Primus . . . ad Romanos (Strasbourg, 1536); M. Bucer, Praelectiones . . . in Epistolam . . . ad Ephesios (Basel, 1562); Common Places of Martin Bucer, ed. D. F. Wright (Abingdon, 1972), pp. 95-118; P. Martyr, In Epistolam S. Pauli Apostoli ad Romanos (Zurich, 1559), esp. pp. 682-743.

${ }^{5}$ E. Cardwell, Synodalia, 2 vols. (Oxford, 1842), 1:23-24; P. Schaff, A History of the Creeds of Christendom, 3 vols. (London, 1877), 3:193-516; see below, pp. 147-48. 
Unlike some later commentators, leading Elizabethan protestants were proud to acknowledge how much they owed to Bucer and Martyr. Walter Haddon, writing at the behest of the English government in 1563 , went out of his way to acknowledge that debt and at the same time did not hesitate to defend predestination-both double and absolute. ${ }^{6}$ Back in 1551, Haddon had delivered the oration at Bucer's funeral and Parker the sermon. Moreover, the continuing pamphlet exchanges during the 1560s between Haddon and the catholic controversialist Jerome Osorio came to turn increasingly on predestination. After the death of Haddon, John Foxe took up the uncompleted task of replying, and a joint work was published in 1577-with some hundred pages devoted to maintaining absolute predestination. ${ }^{7}$ Such Reformed teaching did not, however, go uncontested, and for the first two decades of Elizabeth's reign Lutheran treatises, either in Latin or English translation, propagated an alternative doctrine. The most important author in this context was the Danish Lutheran Neils Hemmingsen. Nevertheless, after about 1580 anti-Calvinist views (as we may now call them) apparently ceased to be printed in England, probably reflecting a tightening of religious censorship. ${ }^{8}$ Some of those concurrently in the forefront of making Calvinist doctrine available in translation were undoubtedly puritans, such as John Field. At the same time, however, dedicatees of these books included Archbishop Edmund Grindal. ${ }^{9}$ The foregoing story has never been investigated in any detail, but enough is already known to suggest that the mid-1590s saw a somewhat desperate attempt by English Lutherans (for want of a better term) to fight back. Although this episode, which produced the notorious Lambeth Articles, is still much disputed by historians, it would be difficult to argue that the Lutherans then regained ground previously lost.

The Anglican school, with which Bernard chooses here to iden-

${ }^{6}$ W. Haddon, A Sight of the Portugall Pearle (London, 1565?), sigs. Biiii, Cvii-Diii. This is a translation of the original Latin edition, which is not known to survive; L. V. Ryan, "The Haddon-Osorio Controversy (1563-1583)," Church History 22 (1953): 142-54. My attention was drawn to this important article by Tom Freeman.

${ }^{7}$ M. Bucer, Scripta Anglicana (Basel, 1577), pp. 876-99; J. Foxe, Contra Hieron. Osorium (London, 1577), fols. 153v-210.

${ }^{8}$ N. Hemmingsen, The Epistle of . . . Saint Paul to the Ephesians (London, 1580), esp. pp. 53-72. This was among the last of Hemmingsen's works to be published in England and is also the most overtly anti-Calvinist.

${ }^{9}$ J. Calvin, Thirteen Sermons . . . entreating of the Free Election of God in Jacob, and of Reprobation in Esau, trans. J. Field (London, 1579); J. Calvin, Sermons . . . upon . . . Ephesians (London, 1577), dedicated by the translator, Arthur Golding, to Archbishop Grindal. Golding writes of "the doctrine of election and predestination" as "being the chief groundwoorke of this epistle to the Ephesians"': sig. *ii. 
tify, has always objected strongly to the employment of such Continental religious terminology in an English context, but it is incontestable that much of the Elizabethan debate on subjects like predestination was conducted through the medium of foreign authors-either Latin republications or English translations. Bernard also proves surprisingly slapdash in his account of the argument that he wishes to refute. Thus we are told that the present writer has claimed that "the dominant doctrine in the early seventeenth-century Church of England was predestination," subsequently coming under attack from "a group of Arminians ... who allegedly followed the teaching of the Dutch theologian Arminius," and I am chided for neglecting the "realities of religious life in the parishes." 10 It would indeed be a rash historian who claimed to have isolated the "dominant doctrine" purveyed countrywide, at this or any other period, although such religious teaching is likely to have been fairly platitudinous and certainly nothing so relatively esoteric as predestination. The "dominance" in question relates to that formulation of the theology of grace most favored by the clerical leadership at various dates. (It is important, however, to emphasize that the early modern disputes about predestination did revolve around the central topic of salvation.) Nor are English antiCalvinists deemed by me to have "followed the teaching" of Arminius. ${ }^{11}$ Furthermore, the concept of dominance itself implies the continued existence of different, less influential teaching. Nonetheless, it is becoming increasingly clear that English and Dutch anti-Calvinists shared a common ancestor in second-generation Lutheranism, specifically involving the work of Hemmingsen. ${ }^{12}$

Bernard and a number of other historians, notably, Sheila Lambert, seek in addition to undermine the notion of Calvinist dominance, prior to the $1620 \mathrm{~s}$, by reference to the undisputed fact that some antiCalvinists became Jacobean bishops. The fallacy, however, of such arguments is that they fail to distinguish the key appointments, to Canterbury and London, and how power was actually exercised. ${ }^{13}$ Regardless of the precise religious sympathies of James I, the de facto situation was that until the 1620 s Calvinists generally controlled the

${ }^{10}$ Bernard, pp. 183, 195-96.

${ }^{11}$ N. Tyacke, Anti-Calvinists: The Rise of English Arminianism, c.1590-1640, 2d ed. (Oxford, 1990), p. 245.

${ }^{12}$ N. Tyacke, "Arminianism," in The Blackwell Encyclopedia of Medieval, Renaissance and Reformation Thought, ed. A. E. McGrath (Oxford, in press).

${ }_{13}$ Bernard (n. 2 above), p. 194; S. Lambert, "Richard Montagu, Arminianism and Censorship," Past and Present, no. 124 (1989): 38-42. Bernard and Lambert also fail to distinguish between "court bishops" and the rest: K. Fincham, Prelate as Pastor: The Episcopate of James I (Oxford, 1990), pp. 41-57. 
English licensing of religious books-under the aegis of Canterbury and London in the capital and the determination of orthodoxy in university disputations. ${ }^{14}$ The evidence on both these counts seems overwhelming and has certainly not been adequately addressed by would-be critics. It was a balance of forces which shifted only in the last years of James. Nevertheless, for Bernard, and those who think like him, the religious policies pursued by Charles I were continuous with those of his predecessor and indeed the Tudor Church. Significantly, he has little to say about the doctrines at issue in the controversy surrounding the publications of Richard Montagu, during the $1620 \mathrm{~s}$. But the teaching of Montagu, as we shall see, especially in his Appello Caesarem of 1625, was actually more dogmatically antiCalvinist than either Arminius himself or the Remonstrance drawn up by his Dutch followers in 1610. Montagu dared to say things they had left unsaid. ${ }^{15}$ Moreover, the upshot of the Montagu controversy was to end a period of Calvinist dominance, traceable from at least the 1580s. Despite his stress on contextualization, Bernard fails to consider either this point or its bearing on the question of puritanism. For, with the English Church now increasingly seen as purveying false doctrine, a new and destabilizing element had been introduced. Purity of doctrine, after all, was one of the conventional marks of a true church.

Part and parcel of Bernard's case, and that of other revisionists, is that no serious religious tensions existed in England before the Scottish rebellion of the late 1630s. The latter, like some deus ex machina, is seen as a sufficient explanation of all that followed thereafter. To this end, these revisionists play down the importance both of puritanism and of ceremonial innovation during the 1630s-the imposition of what contemporaries called the "new" as opposed to the "old conformity." The numbers of puritans are deemed insignificant, and much of the ceremonial change that occurred is ascribed to local rather than central initiatives. Also denied is any link between doctrine and outward forms, especially the alterations to communion tables in parish churches. ${ }^{16}$ Indeed, the rise of Arminianism itself is written off as a myth put about by a handful of puritans, led by the infamous William

${ }^{14}$ N. Tyacke, "Debate: The Rise of Arminianism Reconsidered," Past and Present, no. 115 (1987): 202-4, 207, 208; Bernard, especially, does not appear to understand how religious censorship worked, writing of Laud's "chaplains" licensing books at "Oxford" (ibid., p. 197), where the relevant authority was, of course, the vice chancellor.

${ }^{15}$ See below, p. 154.

${ }^{16}$ Compare, however, K. Fincham, "Episcopal Government, 1603-1640," in The Early Stuart Church, 1603-1642, ed. K. Fincham (Basingstoke, 1993), pp. 71-91. 
Prynne. Those attracted especially by this last argument are now able to cite a book-length study by Peter White, which traverses the same chronological ground as Bernard but concentrates almost exclusively on doctrinal developments.

White is the leading spokesman for the Anglican wing of the revisionist alliance of Civil War historians. His avowed purpose is to reaffirm the continued existence of an Anglican via media in doctrine, stretching from the days of Henry VIII to those of Charles I. White's book, Predestination, Policy and Polemic, consists of a series of case studies devoted to a number of theological writers, interspersed with expositions of particular episodes and periods. The alliteration of the title refers both to the interconnectedness of religion and politics and to what the author regards as the polemical distortions of a middle ground normally inhabited by most theologians. Indeed, White goes so far as to define theology proper as consisting in "the resolution of the great antinomies, of nature and grace, of freedom and necessity, of faith and works," thus effectively privileging his own conception of a doctrinal via media. A further consequence is that whole swathes of religious writing can be dismissed as theologically irrelevant because essentially polemical. Perhaps unsurprisingly, White claims to find few Calvinists or Arminians in pre-Civil War England. Not content, however, with this loading of the dice, he proceeds to define his doctrinal terms in such a way as to eliminate most contenders. Despite the fact that English Calvinists by the early seventeenth century were generally sublapsarians, who conceived of fallen man as the object of predestination, we are presented with a creabilitarian definition of Calvinism: "the doctrine that the decree to predestinate is logically prior . . . to the decree to create." This is, of course, an even more extreme doctrinal position than the usual supralapsarian alternative to sublapsarianism: "the doctrine that the decree to predestinate was logically prior to the decree to permit the fall." Creabilitarianism is a complete red herring. ${ }^{17}$

On the subject of Arminianism, the attempt of White at definition is so opaque as to leave the reader with no real criterion by which to judge particular allegations. Arminius, however, conveniently summed up the difference between himself and his opponents, in the form of the following double-barrelled question: "Do we believe because we have been elected, or are we elected because we believe?" What is more, this formulation is an acknowledged borrowing from Hem-

${ }^{17}$ P. White, Predestination, Policy and Polemic: Conflict and Consensus in the English Church from the Reformation to the Civil War (Cambridge, 1992), pp. 5, 16. 
mingsen. White, however, both fails to quote this passage and denies that Arminius had "any direct link with Lutheranism." Nevertheless, Peter Bertius, in his funeral oration of 1609 , indicated that Arminius abandoned Calvinism under the influence of Philipp Melanchthon and Hemmingsen. Moreover, Hemmingsen and Arminius answered their own question in terms usually expressed as predestination ex praevisa fide-from foresight of faith. A handy source of Dutch Arminian doctrine, although one not used by White, is also provided by their $R e$ monstrance of 1610 . This maintains that predestination is conditional on faith, the offer of grace unrestricted, and its working on the will not infallible. ${ }^{18}$

Clearly White regards himself as specially equipped theologically, at various points alluding to the alleged incompetence of others. We are also encouraged in this opinion by the very flattering prereviews printed on the dust jacket. This book, John Guy tells us, is "a brilliant, and breathtakingly learned, exposition." According to John Morrill, it exhibits a "rare ambition and authority." All the more disappointing then that White provides such a careless analysis of the views he seeks to discredit, in the following terms: "Doctrinally, it is asserted, the English Church was uniformly 'Calvinist' from the beginning of the reign of Elizabeth"; not, "it is argued, until the 1590s" was Calvinism "first challenged" in England, involving an "Arminian assertion of 'the free will of all men to obtain salvation" "; nevertheless, "the majority of the clergy and probably most of the laity" remained "convinced predestinarians"; this Calvinist "consensus" was only overthrown after the accession of Charles I, and the "English Civil War is . . . seen as primarily the result." 19 Unfortunately much of the foregoing (as indicated by italics) is a caricature of the historical argument actually advanced. It also involves at least two serious misquotations from a twenty-year-old essay of mine. What I then wrote was that "the essence of Arminianism was a belief in God's universal grace and the free will of all men to obtain salvation," and that "at the beginning of the seventeenth century, a majority of the clergy . . . were Calvinist in doctrine, and the same was probably true of the more educated laity." ${ }^{20}$ Since most of the population were illiterate at the time, this last point is no mere pedantry. Worse, the mangled quotation about free will implies that the present writer does not understand the

\footnotetext{
${ }^{18}$ White, pp. 22-38; The Works of James Arminius, 3 vols., ed. J. Nichols and W. Nichols (London, 1825-75), 1:30, 578-79; Schaff (n. 5 above), 3:545-49.

${ }^{19}$ White, pp. $x, 1$.

${ }^{20}$ N. Tyacke, "Puritanism, Arminianism and Counter-revolution," in The Origins of the English Civil War, ed. C. Russell (London, 1973), pp. 119-20. My italics.
} 
difference between Arminianism and Pelagianism, the latter denying a need for grace. None of this augurs well for White's likely treatment of sixteenth- and seventeenth-century authors.

True to his Anglican paradigm, White early on glosses official Edwardian doctrine in terms of its Henrician antecedents. This proves all the more necessary because of the damaging admissions he feels compelled to make about the unconditional predestinarianism of Bucer and Martyr. But the King's Book of 1543, produced at the height of the Henrician catholic reaction, and the Forty-Two Articles of 1553 are in reality worlds apart. The former inculcates, among other things, transubstantiation and justification by works as well as faith, in addition to emphasizing free will in a way that many Edwardian protestants would find deeply offensive. White rightly points out that some of the Edwardian leaders, preeminently John Hooper and Hugh Latimer, held views on predestination very different from Bucer and Martyr. Latimer was pretty clearly what in later parlance would be called an Arminian. ${ }^{21}$ The question, however, remains as to where the theological center of gravity had come to rest by the death of Edward VI. Remarkably, we still lack a modern and authoritative account of the Edwardian Reformation that might enable us to answer that question with confidence. Yet the role of Cranmer appears crucial, particularly in the formulation of the Forty-Two Articles-produced at the very end of the reign. Given the likely competing pressures on him, the fairly uncompromising stance on predestination, of article 17, is all the more striking. Thus there is no suggestion that election- "predestination to life" - is conditional on faith. On the contrary, "such as have so excellent a benefit of God given unto them, be called according to God's purpose, by his spirit working in due season, they through grace obey the calling, they be justified freely, they be made sons by adoption, they be made like the image of God's only begotten son Jesus Christ, they walk religiously in good works, and at length by God's mercy, they attain to everlasting felicity." The word "reprobation" is not used as such, although it occurs in the associated $R e$ formatio Legum Ecclesiasticarum. Nevertheless, the article does refer to the pastoral danger that consideration of the "sentence of God's predestination" may drive "curious and carnal persons, lacking the spirit of Christ," to "desperation or into recklessness of most unclean living." At the very least, we are dealing here with a concept of nonelection-the negative counterpart to "the everlasting purpose of

${ }^{21}$ White, pp. 39-52, 54, 56; C. Lloyd, ed., The King's Book (London, 1932), pp. $10=13,50-51,147-63$. 
God ... to deliver from curse and damnation those whom he hath chosen out of mankind.",22

With some very slight changes, the Edwardian article on predestination was incorporated into the Elizabethan Thirty-Nine Articles of 1563. Meanwhile, the related Oxford and Cambridge lectures of Martyr and Bucer were published in the years immediately preceding; those by Martyr came out in 1559, dedicated to Sir Anthony Cooke, while Bucer's appeared in 1562, dedicated by the editor to Sir Nicholas Throckmorton. ${ }^{23}$ We have already noted the 1563 exchange between Haddon and Osorio on the same subject. Apparently unaware of these developments, White chooses to discuss instead the views of the Elizabethan protestant apologist John Jewel. In the light of the well-known close personal links between Jewel and Martyr, we might have expected them to hold similar theological views. White, however, uses Jewel's published sermons on Thessalonians in order to deny this. Yet, employing the same source, it is possible to reach a different conclusion and one more in line with our initial expectations. Jewel speaks of the "company of the faithful," their "names written in the book of life," the "elect," who "shall never perish." He cites St. Augustine that to one "it is given to believe, to the other it is not given." God "only disposeth the ways of men" and "knoweth whom he will bring to be of his fold." As for the "wicked," this "is a token of God's heavy displeasure upon them that they repent not of their former evils, but grow worse and worse." Those who Antichrist will deceive are they "whose names are not written in the book of life." But "God hath chosen you from the beginning; his election is sure for ever." You "shall not fall from grace, you shall not perish." None of these passages, however, are quoted by White. Moreover, looking ahead, he concludes that there is "nothing" in Jewel "which would have helped the Cambridge opponents of Baro and Barrett in the conflict that led to the Lambeth Articles." His deduction is the more extraordinary because Peter Baro, like Arminius, taught predestination ex praevisa fide. ${ }^{24}$

Appropriately enough, White then turns to a consideration of Henry Bullinger, whose Decades acquired a quasi-official status in Elizabethan England. The discussion which follows, however, is very

${ }^{22}$ Cardwell, Synodalia (n. 5 above), 1:23-24; White, pp. 57-59; E. Cardwell, ed., The Reformation of the Ecclesiastical Laws (Oxford, 1850), p. 21.

${ }^{23}$ Cardwell, Synodalia, 1:63-64; see n. 4 above.

${ }^{24}$ White, pp. 72-74; The Works of John Jewel, 4 vols., ed. J. Ayre, Parker Society (Cambridge, 1845-50), 2:819, 821-22, 828, 841, 923, 933; H. C. Porter, Reformation and Reaction in Tudor Cambridge (Cambridge, 1958), pp. 386-89. 
confused, with contrary positions being ascribed to Bullinger in successive paragraphs. First we are told that Bullinger's teaching on "election" is a "remarkable and explicit anticipation of what was later called Arminianism." But then we learn that Bullinger taught that "faith is the result of election." A possible explanation might be that Bullinger had changed his mind, yet White assures us that he "never withdrew" his earlier remarks. In fact, the doctrine of the Decades is compatible with what comes to be known as sublapsarian Calvinism. Here and elsewhere, White appears to mix up the latter with what he calls "single predestination," although no definition is provided. ${ }^{25}$ Moreover, on the face of it, rather surprising is that, among other Continental theologians "popular" in Elizabethan England, Hemmingsen rates less than two pages. Can this be because Hemmingsen's strong endorsement of conditional predestinarian views undermines the concept of a doctrinal "spectrum" so much canvassed by White? Equally sketchy is the treatment afforded the sermon preached by Samuel Harsnett at Paul's Cross, in 1584. The context of this antiCalvinist sermon, which nearly ruined Harsnett's career, cries out for investigation. According to White, however, it was not the doctrinal content of what Harsnett preached that got him into trouble with Archbishop John Whitgift, but making "Geneva his target." This seems highly unlikely, not least because of the type of predestinarian teaching that Whitgift can be found personally licensing only a few years afterward..$^{26}$

While it is indeed the case that the doctrinal controversies of the 1590s, culminating in the Lambeth Articles, need to be viewed in the light of the contemporary puritan vogue for supralapsarian teaching on predestination, it does not follow that the disputes were simply puritan-inspired. A major contributor, for instance, was Bishop Gervase Babington. ${ }^{27}$ White also signally fails to recognize the threecornered nature of these debates, involving Arminians avant la lettre and Calvinists of both supralapsarian and sublapsarian varieties. He resolutely refuses to accept that the archbishops of Canterbury and York, Whitgift and Matthew Hutton, were either of them "in any

\footnotetext{
${ }^{25}$ White, pp. 74-75, my italics; The Decades of Henry Bullinger, 4 vols., ed. T. Harding, Parker Society (Cambridge, 1841-52), 3:185-95; see below, pp. 151-52.

${ }^{26}$ White, pp. 89-90, 99-100; Tyacke, Anti-Calvinists (n. 11 above), pp. 32, 164-65, 251-52; his surviving library suggests that Harsnett was in touch with Lutheran teaching: G. Goodwin, A Catalogue of the Harsnett Library at Colchester (London, 1888), pp. $5,12,120,163$.

${ }_{27}^{27}$ Tyacke, Anti-Calvinists, pp. 29, 31, 38; P. Lake, Moderate Puritans and the Elizabethan Church (Cambridge, 1982), p. 150; G. Babington, A Sermon preached at Paules Crosse (London, 1591); compare White (n. 17 above), pp. 95-97.
} 
meaningful sense a Calvinist," and sees the Lambeth Articles as intended "to put a rein on both Calvinists and anti-Calvinists" alike. This interpretation, however, is only possible because of White's exclusive definition of Calvinism. In actuality, both Whitgift and Hutton, as well as the Lambeth Articles, are best understood as speaking the language of sublapsarian Calvinism. Albeit positing fallen man as the object of predestination, such Calvinists still taught an unconditional form of double predestination. Just how much turns on this point can be illustrated by the fact that the canons of the Synod of Dort, which condemned Arminianism in 1619, similarly enshrined sublapsarian Calvinism. Furthermore, underlying the Cambridge crisis in 1595 were the teachings of Peter Baro-the Lady Margaret professor of divinity. Here it is vital to grasp that Baro, like Hemmingsen and Arminius, taught predestination ex praevisa fide-that is, election was conditional on belief. To describe the Arminianism of Baro, albeit avant la lettre, as coming across as rather muffled in White's account would be an understatement. But, as even White concedes, Baro was the main "target" of the Cambridge Calvinists. A final irony is that in outlining the doctrinal position of Archbishop Hutton, White actually provides a working definition of sublapsarian Calvinism, although he seems quite unaware of this. "Election refers to the purpose of God to separate in Christ those he has chosen out of the corrupt mass. The reprobate are those who are left in the mass.",28

In the Anglican tradition, Richard Hooker is regarded as a kind of keeper of the lamp-the theologian whose writings above all illuminate the via media. Understandably, White objects strongly to the recent demonstration, at the hands of Peter Lake, of just how avantgarde Hooker was. Hooker matters, so Lake argues, not so much for his implicit anti-Calvinism as for his articulation of a new style of sacrament-centered piety that came to its full fruition during the Laudian ascendancy. Lake has now gone on to trace these Hookerian developments in the Jacobean Church, particularly in the thought and practice of those two seminal figures Lancelot Andrewes and John Buckeridge. ${ }^{29}$ White, by contrast, reiterates the conventional view of Hooker as spokesman for a middle way, which continued to characterize the English Church after the accession of James I. Yet at the Hamp-

${ }^{28}$ White, chap. 6; Tyacke, Anti-Calvinists, pp. 30-33; Schaff (n. 5 above), 3:581-85.

${ }^{29}$ White, chap. 7; P. Lake, Anglicans and Puritans? Presbyterianism and English Conformist Thought from Whitgift to Hooker (London, 1988), chap. 4; P. Lake, "Lancelot Andrewes, John Buckeridge and Avant-Garde Conformity at the Court of James I," in The Mental World of the Jacobean Court, ed. L. Peck (Cambridge, 1991), pp. 113-33. 
ton Court Conference of 1604 , the puritans sought to press home the attack on Arminianism avant la lettre. Granted that they failed in their bid to have the teaching of the Thirty-Nine Articles tightened up as regards predestination, a revised commentary on the articles by Archbishop Richard Bancroft's chaplain, Thomas Rogers, was published in 1607. White remains adamant that Rogers did not take "a 'Calvinist' stance on the matters in dispute at Cambridge in the 1590s." Again, however, the text is capable of yielding a different and Calvinist answer. The first point to make is that Rogers quite explicitly interprets article 17, on predestination, in the light of the Second Helvetic, Gallican, and Belgic Reformed confessions of faith. Second, Rogers maintains that both election and reprobation are unconditional: "Of the mere will and purpose of God some men in Christ Jesus are elected, and not others, unto salvation." Opposed to this is the view that "God beheld in every man whether he would use his grace well, and believe the gospel or no; and as he saw a man affected, so he did predestinate, choose, or refuse him." Furthermore, another error is that "no certain company be foredestined unto eternal condemnation." There is no suggestion in Rogers that anyone other than the elect can achieve salvation. Nor should we be surprised that Rogers was chaplain to Bancroft, since the latter as bishop of London can be found personally licensing a full-blooded Calvinist treatise in $1598 .^{30}$

Even when confronted with so obvious a Jacobean Calvinist as Robert Abbot, brother of the archbishop of Canterbury, White seeks to distinguish between his eirenical and polemical "faces." Only the former is deemed to represent genuine "theology." But since the distinction hinges on Abbot's being a sublapsarian Calvinist, which is manifest throughout his published work, it appears meaningless. ${ }^{31}$ The treatment, however, of the anti-Calvinists John Overall and Richard Thomson, as alleged exponents of the Anglican middle way, calls for more discussion here. In Overall, at least, we have a genuine single predestinarian, that is to say someone who apparently taught that there existed a special category of unconditionally elect side by side with others, probably a majority, who might or might not with the assistance of God's grace achieve salvation. This is quite different from the sublapsarian Calvinist view that the reprobate are condemned as a

${ }^{30}$ White, pp. 150-52; T. Rogers, The Catholic Doctrine of the Church of England, ed. J. J. S. Perowne, Parker Society (Cambridge, 1854), pp. 147-49, my italics; Tyacke, "Debate" (n. 14 above), p. 203.

${ }^{31}$ White, pp. 157-59, 169. White also refers to Robert Abbot indulging in "polemic" for "the benefit of undergraduates," although his "students" would in reality have been pursuing a postgraduate course in theology: ibid., p. 157. 
consequence of original sin. By contrast, Overall's formulation granted the essence of the Arminian case, namely, that the "promise of the Gospel" is "conditional." 32 Richard Thomson may also have been a single predestinarian. Certainly Overall helped to arrange for the posthumous publication abroad of Thomson's treatise De Amissione et Intercisione Gratiae, in 1616. Nevertheless, what must strike any reader who compares Thomson's De Amissione with the De Sanctorum Perseverantia et Apostasia of the Dutch Arminian Peter Bertius, first published in 1610 , is how closely allied they are. Indeed, apart from the choice of title by Bertius, his views on falling from grace seem almost indistinguishable from those of Thomson. Both teach that the truly justified may fall, temporarily or permanently. Apropos the falls of the elect, Thomson speaks of "intercision" rather than "apostacy." Neither taught that the elect could fall finally; this would anyway have involved a contradiction as regards election ex praevisa fide, which assumes faith at the last. None of this is explained by White or, in the case of Bertius, even mentioned. Instead, we are told that "no theologian in the Church of England taught that the elect might fall finally in this period." Yet, even on White's own previous showing, neither did Arminius. ${ }^{33}$ Such are some of the foundations of the purported via media in doctrine.

The participation of a British delegation at the Synod of Dort, which condemned Arminianism in 1619, has always posed a potential problem for those writing from an Anglican standpoint. Until recently they tended to ignore it. Since this is no longer possible, they are now obliged to explain Dort away. But, rather than ascribe these events to the international exigencies of the time, White questions the Calvinism of the delegation itself. Indeed he goes further, claiming that the Dort debates "confirmed" the "thrust of English theology" as "a middle way," that "concentrated on fundamentals and avoided extremes, but nevertheless was comprehensive and eirenic." The fact that the delegation included no anti-Calvinists is, however, ignored. Furthermore, the joint Suffrage which the British delegates produced was quite clear in its repudiation of the main Arminian points at issue. This despite the fact that John Davenant and Samuel Ward subscribed to what is known as a hypothetical universalist view of Christ's atonement,

${ }^{32}$ White, pp. 165-66; W. Goode, The Doctrine of the Church of England as to the Effects of Baptism in the Case of Infants (London, 1850), pp. 126-30.

${ }^{33}$ Tyacke, Anti-Calvinists (n. 11 above), p. 36; White, pp. 36-37, 167-74; R. Thomson, Diatriba de Amissione et Intercisione Gratiae et Justificationis (Leiden, 1616); P. Bertius, Hymenaeus Desertor, sive de Sanctorum Perseverantia et Apostasia (Leiden, $1610)$. 
which attempted to reconcile universal redemption with unconditional predestination. We can acknowledge the comparative moderation of the British delegation without having to deny their Calvinism. Moreover, it is a Calvinism which, contrary to White, has clear affinities with that of the Lambeth Articles drawn up almost a quarter of a century earlier. Most obviously, this involves a shared sublapsarianism. ${ }^{34}$ Nevertheless, the ensuing anti-Calvinist reaction of the $1620 \mathrm{~s}$ was more marked than that of the 1590 s, and with very different end results. Cambridge was again a focus. Matters came to a head there during the Commencement in 1622, revealing, in White's words, "very significant support" for the Dutch Arminians. A Calvinist following, led by the Dort delegate Samuel Ward, confronted an Arminian group headed by Leonard Mawe. Ward was the Lady Margaret Professor and Mawe the vice chancellor, and each backed rival theological spokesmen. ${ }^{35}$

Having himself drawn attention to the extent of this doctrinal division, White then rapidly moves to play it down. There "were on both sides moderates looking for a middle way; the reality was a spectrum and not merely polarities." The exemplars of moderation singled out in this context by White, Walter Balcanqual and Jerome Beale, are however very odd. Balcanqual had been one of the hard-liners among the British delegation to Dort, who sought to restrict the benefits of Christ's atonement to the elect. As for Beale, by the late 1620s he can be found interpreting the teaching of the Thirty-Nine Articles in terms of predestination ex praevisa fide. The Cambridge disputes of July 1622 almost certainly contributed to the issuing that August of royal directions restricting preaching on predestination. ${ }^{36}$ But it is above all the Montagu controversy, which broke out two years later in 1624, that has rightly exercised historians. Was Richard Montagu an Arminian, and why did James I support him? That Montagu and his immediate backers were all Cambridge men is probably not coincidental. At the same time, it is widely agreed that the changing international situation, in particular James's pursuit of a Spanish alliance, benefitted the anti-Calvinists. Sheila Lambert, in the article already mentioned, has recently reviewed the evidence. She is quite correct to stress the

${ }^{34}$ White, p. 202; The Collegiate Suffrage of the Divines of Great Britaine concerning the Five Articles controverted in the Low Countries (London, 1629); Tyacke, AntiCalvinists, chap. 4.

${ }^{35}$ White, pp. 208-9; Tyacke, Anti-Calvinists, pp. 46-47.

${ }^{36}$ White, p. 209; Tyacke, Anti-Calvinists, pp. 50-51, 96-97, 102-3. White's treatment here of the surviving Beale-Ward correspondence is particularly unsatisfactory: White, p. 234, no. 107. 
private royal backing for Montagu's book, $A$ New Gagg, in advance of publication, and has convincingly redated some of the surviving letters. But the book as printed exhibits a number of odd features, not least its lack of any dedication. Again, neither she nor White are able to instance any comparable previous publication. It is also unclear just how much James actually read in manuscript of $A$ New Gagg or of Montagu's subsequent defense-Appello Caesarem. ${ }^{37}$ Yet the very fact that the supporters of Montagu, notably Bishop Richard Neile, sought advance royal approval for what in origin purported to be merely an anti-catholic pamphlet indicates just how much was at issue. Montagu indeed looks to have been the stalking horse for a court-based faction of leading clergy, who sought not merely to counteract the effects of Dort but fundamentally to alter the doctrinal stance of the English Church concerning predestination and much else.

The extreme distaste with which Montagu regarded Calvinism is revealed in a surviving manuscript commonplace book, where he refers to the "execrable impiety" of "Calvin's opinion concerning the antecedent immutable decree of predestination." ${ }^{38}$ A New Gagg, however, compared with Appello Caesarem, is a relatively cautious book; so much so that not only the Calvinist Joseph Hall but even the puritan Henry Burton, at least initially, felt able to judge it charitably. ${ }^{39}$ On the basis of the first book it was possible to argue that Montagu, like Overall before him, taught a form of single predestination. Yet in $\mathrm{Ap}$ pello Caesarem he abandoned any such pretense, teaching predestination ex praevisa fide without qualification. Moreover, in maintaining there that the truly justified can fall both totally and finally, Montagu went beyond Arminius and embraced the same position as Bertius. Arminius himself had only gone as far as to say that "there are passages of scripture which seem to me to wear this aspect." Similarly, the Arminian Remonstrance of 1610 concluded that the possibility of falling from grace "must be more particularly determined out of holy scripture, before we ourselves can teach it with the full persuasion of our minds. " 40 Unless we are to assume that they misunderstood Montagu, it is remarkable that five English bishops felt able to affirm in

${ }^{37}$ Lambert (n. 13 above), pp. 42-50.

${ }^{38}$ Archbishop Marsh's Library, Dublin, MS Z4.2.10, fols. 151v-52.

${ }^{39}$ The Works of ... Joseph Hall, 10 vols., ed. P. Wynter (Oxford, 1863), 1:xliii-xliv, 9:489-516; H. Burton, Truth's Triumph over Trent (London, 1629), pp. 341-43. On internal evidence, this book was written when James I was still alive: ibid., pp. 314-15.

${ }^{40}$ R. Montagu, Appello Caesarem (London, 1625), pp. 21-22, 28-30, 56-59, 64-65, 73-74; The Works of James Arminius (n. 18 above), 1:603; Schaff (n. 5 above), 3:54849; see above, pp. 151-52. 
January 1626 that he "hath not affirmed anything to be the doctrine of the Church of England but that which in our opinions is the doctrine of the Church of England, or agreeable thereunto." ${ }^{41}$ Although Montagu's Appello Caesarem was eventually suppressed, on the basis of a royal proclamation in 1629 , by then the controversy had served its purpose.

Despite paraphrasing the teaching of Montagu in Arminian terms, that "predestination to life was the work of God to draw out of misery those who will take hold of his mercy," White exonerates him from the charge of Arminianism. However, a few pages later, we are told that at the York House Conference, in February 1626, Montagu "was obliged to admit that he had gone too far in asserting that the Church of England had determined against irrespective election." Nor does White adequately ponder the implication of the fact that despite rejecting his father's foreign policy Charles I did not abandon Montagu. Although the court remained far from monolithic in its religious views, the Calvinists had nonetheless lost out by the end of the 1620s. William Herbert, third earl of Pembroke, whom White confuses with his brother Philip, fourth earl of Pembroke, was at best able to conduct a rear-guard action on their behalf. As early as June 1626, when preaching before the king, the Calvinist Archbishop James Ussher protested against the trend of religious policy. That October, following on the death of Lancelot Andrewes, William Laud was promised the succession to Canterbury-still occupied by the Calvinist Archbishop George Abbot. Meanwhile, Laud became dean of the chapel royal. Calvinist professors at Oxford and Cambridge, as a consequence of the royal declaration of 1628 silencing controversy, were obliged to adapt their teaching. The same year Laud put an end to Calvinist preaching from the famous Paul's Cross pulpit in London, terminating indeed an "unchallenged Calvinist oration" there stretching back to the $1580 \mathrm{~s}$. Montagu was also promoted to the episcopate in 1628, although the rumor that he had recanted Arminianism seems to have been wishful thinking on the part of Calvinists. ${ }^{42}$

Both in the immediate future and the longer term, the doctrinal changes of the 1620 s were to prove decisive - not as White would have it with the establishment of a "judicious agnosticism," but in the

${ }^{41}$ The Works of William Laud, 7 vols., ed. W. Scott and J. Bliss, Library of AngloCatholic Theology (Oxford, 1847-60), 6:249.

${ }^{42}$ White (n. 17 above), pp. 221, 229, 250, and index refs. to "Pembroke"; Tyacke, Anti-Calvinists (n. 11 above), pp. 49, 50-51, 76-79, 249, 261; N. Tyacke, "Archbishop Laud," in Fincham, ed. (n. 16 above), p. 64; compare Porter (n. 24 above), p. 287, quoted by Bernard (n. 2 above), p. 192. 
eclipse of Calvinism. Here university teaching is the most obvious litmus test of the changing concept of orthodoxy, Calvinism disappearing from the Cambridge Commencement in the mid-1620s and from the Oxford Act after 1631. Catholics and puritans were each to comment on the alteration which involved much more than simply the theology of grace. ${ }^{43}$ Symptomatic of the new theological tendency are the publications of Thomas Jackson, whose Arminianism White characteristically denies although noting his agreement with Hemmingsen. One of the striking things, however, about the published teaching of Jackson is the marked change from 1628 onward, reflecting almost certainly a climate more favorable to his true views. Meanwhile, Jackson's critics were obliged to publish abroad..$^{44}$ As regards the Arminian sympathies of Laud and Neile, it is very important to grasp that their views had changed over time. Thus the fact that Neile's denial of Arminianism, in 1629, was phrased in the past tense appears highly significant. Laud's own condemnation of the Lambeth Articles, in 1625 , is dismissed by White as mere "anti-Calvinist polemic." By contrast, he describes even so stridently an anti-Calvinist work as Edmund Reeve's Communion Booke Catechism, of 1635, as containing "nothing" that "any communicant would not have heard countless times in his parish church at any time since the accession of Elizabeth." As well as citing Jackson on predestination, Reeve couched his argument in terms of the "old doctrine" of the prayer book versus the "new" teaching of the Calvinists and sought to demonstrate the incompatibility of the latter with sacramental grace. Reeve also wrote of the desirability of doing reverence to the altar-God's "mercy seat." 45 White, however, ignores such ceremonial matters. By contrast, they are of central concern to Julian Davies in his book The Caroline Captivity of the Church. ${ }^{46}$

Davies, like White, regards the rise of English Arminianism as a fiction and devotes a rather short chapter to this theme. He is unwilling to concede that even Richard Montagu was a genuine Arminian, writ-

${ }^{43}$ White, p. 254; Tyacke, Anti-Calvinists, pp. 48-49, 81, 224, 227; N. Tyacke, "Arminianism and the Theology of the Restoration Church,' in Britain and the Netherlands, vol. 11, ed. S. Groenveld and M. Wintle (Zutphen, 1994).

${ }^{44}$ White, p. 270; Tyacke, Anti-Calvinists, p. 121; W. Twisse, A Discovery of D. Jackson's Vanitie (Amsterdam, 1631); S. Rutherford, Exercitationes Apologeticae pro Divina Gratia (Amsterdam, 1636), pp. 351-55.

${ }^{45}$ White, pp. 242, 274, 297; Tyacke, Anti-Calvinists, pp. 109-13, 266-68; Tyacke, “Archbishop Laud,' pp. 58-60; E. Reeve, The Communion Booke Catechisme Expounded (London, 1635), sig. C2r-v, pp. 48, 66-67, 132-37.

${ }^{46} \mathrm{~J}$. Davies, The Caroline Captivity of the Church: Charles I and the Remoulding of Anglicanism (Oxford, 1992). 
ing of his "near-Arminian views on foreseen faith and falling from grace." Davies claims that Laud and the other supporters of Montagu were single predestinarians, because they concentrated their criticisms on the doctrine of reprobation. This, however, was a standard antiCalvinist ploy and by itself proves nothing. More specifically, his assertion that the hostile reference by Buckeridge, John Howson, and Laud, in 1625, to the "fatal opinions" contained in the Lambeth Articles must by definition refer to "reprobation" can be refuted on the basis of a quotation from Hemmingsen - conveniently supplied by Peter White. Hemmingsen adjured "that we seek not our assurance of faith or hope in the tablets of the fates." 47 Unconditional election, from an anti-Calvinist point of view, could thus be equally "fatal." In addition, Davies fails to distinguish the earlier views of Laud from those which he later espoused, compounding matters by mistranslating "renatos" as "elect" instead of regenerate. What Laud actually wrote, in a comment probably dating from the first decade of the seventeenth century, was that the "regenerate" — a much broader categorycannot fall into final impenitency. As White has written, in another context, the difference is "fundamental," and had Laud still held this view in the mid-1620s his support for Montagu would indeed be difficult to explain..$^{48}$ Davies also says that the royal declaration of 1628 , far from proscribing "single predestinarian Calvinism," actually "endorsed" it, although he fails to explain why the moderate Calvinist Bishop Davenant was so severely reprimanded for merely touching on the doctrine of election in a court sermon of 1630 . Not only is the very concept of "single predestinarian Calvinism" a contradiction in terms, but the reader may well be unaware that in this context Davies quotes from the Thirty-Nine Articles rather than the declaration itself. The latter purported to silence all parties. ${ }^{49}$

Like White too, Davies writes from an Anglican standpoint. Nevertheless, there are some very important differences. The Caroline "captivity" of the book's title refers to what Davies sees as the distortion of Anglicanism by Charles I. Although he also refers rather vaguely to Laud's attempted "recatholicization" of the English Church, it is Charles who occupies the center stage in this account. Essentially we are offered a challenging, but deeply flawed, political interpretation of religious change, in terms of something called "Car-

\footnotetext{
${ }^{47}$ Davies, pp. 95-97; White, p. 270; Tyacke, Anti-Calvinists, pp. 266-67.

${ }^{48}$ Davies, p. 96; Tyacke, "Archbishop Laud," p. 58; White, p. 108.

${ }^{49}$ Davies, pp. 117-18; White, pp. 251-52, 299-300. As with White, Davies never makes clear what he means by "single" predestination.
} 
olinism" and the concept of "caesaro-sacramentalism." In the eyes of Charles the altarwise communion table was, says Davies, a "visual and mnemonic means of impressing a greater respect for his pretensions to divine right among the people." The king allegedly sought to diffuse "his own cult and apotheosis-an imago dei, which found its most disturbing icon in the face of Christ, commissioned by [Bishop] John Williams in 1631 for the east window of his new chapel at Lincoln College, Oxford." This somewhat cryptic last remark refers to the picture on the dust jacket (not reproduced in the book), which shows a Charles-faced Jesus presiding over the last supper. "Through the manipulation of divine worship and its setting, Charles I's pretensions to sacramental kingship received not only visual expression but the cloak of divine respectability." ${ }^{50}$ Apart from the Lincoln College window, the main evidence adduced in this connection is a handful of sermons preached during the 1630s. Why, however, these should represent the views of Charles rather than of the preachers concerned is unclear. In order to inculcate reverence to the altar, Thomas Laurence and others drew an analogy between it and the chair of state in the royal presence chamber. But they did not confuse the two, and Laurence indeed went out of his way to distinguish. "Nor is all this to insinuate the derivation of God's honour upon any besides God. (God divert that damnable idolatry as far from me, as hee hath done from the church of God.)." This denial is not quoted by Davies, who writes instead of "Caroline idolatry" being destroyed in the 1640s. ${ }^{51}$ More dubious still is his attempt to show that "Calvinists" also were "prepared to practise and vindicate the novel modes of worship." Here we are told that the Calvinist Walter Balcanqual "stressed the exemplar of Charles's approach to the [communion] table." Yet the passage cited has nothing to do with either Charles or communion tables and relates instead to kneeling at prayer. Equally malapropos are the references to the Calvinist Daniel Featley, who refused to turn the communion table altarwise in Lambeth parish church, and the Calvinist Dean John Young who had to defend himself from the charge of "not bowing to the altare" in Winchester cathedral. ${ }^{52}$ Thus the evidence for caesaro-

${ }^{50}$ Davies, pp. 15, 206, 299.

${ }^{51}$ Davies, pp. 18-19, 317; T. Laurence, A Sermon preached before the King's Majesty at Whitehall (London, 1637), p. 25.

52 Davies, pp. 19-20; W. Balcanqual, The Honour of Christian Churches (London, 1633), p. 12; D. Featley, The Gentle Lash or the Vindication of Dr. Featley (London, 1644), p. 10; The Diary of John Young, ed. F. R. Goodman (London, 1928), pp. 108-9. 
sacramentalism appears to reduce to a piece of flattery by Bishop Williams, but even he did not seek to identify King Charles with the crucified Christ.

Davies repeatedly accuses the present writer of introducing a wrongheaded "Weberian polarity between grace and predestination," into modern accounts of the early Stuart Church. This, however, misstates my original proposition, which does not moreover depend on Max Weber. By the end of the sixteenth century, the relationship between the grace of election and that which came via the sacraments was a well-worn theme in debates between Calvinists and Lutherans, surfacing for example at the Colloquy of Montbéliard in 1586. Like the Continental Lutherans, English anti-Calvinists came to argue that a true valuation of the sacraments was incompatible with absolute predestination. During the 1630s they made a further linkage, while urging reverence to the altar-often itself a recently converted communion table. Thus there are frequent references to the altar as God's "mercy-seat." When Laurence, Reeve, and Robert Shelford use this phrase, it seems reasonable to assume they mean the merciful grace of God mediated to all penitent sinners through the eucharist. ${ }^{53}$ But here Davies plays what he evidently regards as a trump card, claiming that one of the most vigorous enforcers of the altar changes in the 1630s was the Calvinist Bishop John Davenant of Salisbury-although paradoxically conceding that "there is reason to believe that he would rather they had not been introduced." Nevertheless, Davies is only able to produce a single early case of enforcement under Davenant, that of Edington, Wiltshire, in October 1635. Even on his own showing there were untypical features to the Edington case, not least the apparently unique requirement to "rail in the font" as well as the communion table. In reality the initiative was almost certainly that of Lady Anne Beauchamp, sister to the earl of Dorset and a close friend of Secretary Francis Windebank, who had recently erected a monument to her late husband in the chancel of Edington church. This monument too appears originally to have had a rail around it. Davies fails to alert the reader to the fact that Lady Anne is actually mentioned in the court record. Nor does her name feature at all in his account. ${ }^{54}$ Yet

${ }^{53}$ Davies, pp. 50, 92, 122, 299; Tyacke, Anti-Calvinists, pp. 10, 39, 52, 55, 175-76; J. Raitt, The Colloquy of Montbéliard: Religion and Politics in the Sixteenth Century (New York, 1993), chap. 5; T. Laurence, Two Sermons (Oxford, 1635), 1:37; Reeve, pp. 132-37; R. Shelford, Five Pious and Learned Discourses (Cambridge, 1635), pp. 4, 15.

${ }^{54}$ Davies, pp. 223-25; Wiltshire Record Office, Trowbridge, D1/41/1/2, Citations 
more damaging to Davies's argument concerning Bishop Davenant are events at Newbury, Berkshire. In 1634 the Newbury churchwardens reportedly had been ordered by Laud's vicar-general, at the metropolitical visitation, to move their communion table. They had still not done so by June 1637, when the case disappears from view. The court latterly responsible was that of Archdeacon Edward Davenant, the bishop's nephew..$^{55}$ Davies also has an odd way with statistics, deducing compliance from silence. Not in fact until the years 1637 and 1638 is there much evidence of communion tables being either moved or railed, in Salisbury diocese.$^{56}$ By this time, most dioceses bear witness to the impact of the Caroline altar policy.

The implausible attempt to portray Bishop Davenant as a Calvinist ceremonialist is, however, part of a much wider endeavor by Davies to dissociate Archbishop Laud from the religious policy of Charles I. He purports indeed to have discovered no less than six different ceremonial strategies being pursued during the 1630s in the various dioceses of England and Wales. Rather than talk of an altar policy, he writes of the "table of separation" and weaves a complex web in terms of the positioning and railing of communion tables as well as the place where communicants knelt. Nevertheless, many of his distinctions can be shown to be spurious. For example, his assertion that in the diocese of London, under Bishop William Juxon, the altarwise position was not enforced is based on a misreading of the surviving records. Misled by subsequent abbreviations, Davies neglects to note that all parishes in the archdeaconry of St. Albans were instructed by Laud's vicargeneral in 1637 " to remove theire communion table to the upper end of theire chancell and place it alonge the east wall, and compasse it with a convenient and decent rail." By the end of the year all twenty-

1635; Victoria County History, Wiltshire 8 (1965): 248; C. E. Ponting, "Edington Church," Wiltshire Archaeological and Natural History Magazine 25 (1891): 224; Calendar of State Papers Domestic, 1635-6, p. 378.

${ }_{55}$ Berkshire Record Office, Reading, D/A2/c.77, Acta (Berkshire Archdeaconry), 1635-6, fols. 81v-82, D/A2/c.78, Acta (Berkshire Archdeaconry), 1636-7, fol. 255v. The rector of Newbury was the famous Calvinist William Twisse-future prolocutor of the Westminster Assembly. Davies does not discuss this case, although it features anonymously and repeatedly in his footnotes as evidence of "enforcement": Davies, $p$. 224, nn. 76, 80.

${ }^{56}$ Wiltshire Record Office, Trowbridge, D2/4/1/16, Acta (Salisbury Archdeaconry), 1636-41, fols. 32, 65v, 113v, D3/4/7, Acta (Wiltshire Archdeaconry), 1632-42, fol. 56v. It was in March 1638, not December 1637 (Davies, p. 225), that the churchwardens of Fifield were ordered to move and rail their communion table "as in other churches the same is done": D3/4/7, fol. 56v. I have discussed elsewhere the Aldbourne, Wiltshire, case of May 1637: Tyacke, Anti-Calvinists, pp. 210-12. 
six parishes had certified obedience. ${ }^{57}$ Again, we are told that in Canterbury diocese Laud did not enforce reception at the rails; but the records tell a different story. Thus, in December 1637, the minister at St. James' Dover was ordered to remain "within" the rail when administering communion-according to the vicar-general's charge "throughout the diocesse at the last ordinary visitation." ${ }^{58}$ Similarly, the claim that Laud did not advocate an altarwise position for communion tables flies in the face of the archbishop's reiterated assertion that this was still a binding requirement under the Elizabethan injunctions. ${ }^{59}$ Davies also makes extensive use of a deposition by William Stackhouse, a parishioner involved in the famous St. Gregory's, London, case of 1633, concerning the position of the communion table, and appears to regard it as reliable. Yet he conceals Stackhouse's statement that in 1633 Laud had argued, against both King Charles and Archbishop Richard Neile, in favor of a permanent altarwise position for the communion table. ${ }^{60}$ Granted the complexity of the evolution of Caroline altar policy, Davies has done a serious disservice by sowing so much confusion. Furthermore, attention is distracted from the very real quarrel between Laud and Bishop Williams, which may date back to the late 1620s and the activities of one of Laud's archdeacons, Thomas Rayment of St. Albans, as rector of Ashwell within Williams's own diocese of Lincoln. Although Davies obfuscates matters, Williams recommended an east-west position for parish communion tables as opposed to a north-south or altarwise one. Laud appears always to have favored the latter. ${ }^{61}$

The cautiousness-even the statesmanlike qualities-of Laud's handling of religious matters during the 1630s are not in question. But was Laud really the unwilling executant of royal policy? Much is made by Davies of the influence on Charles of Lancelot Andrewes as dean of the chapel royal, yet the king chose Laud as successor to Andrewes

57 Davies, pp. 218, 227-29, and chap. 6 generally; Hertfordshire Record Office, Hertford, ASA7/31, Acta (St. Albans Archdeaconry), 1636-38, fols. 36v-37, my italics. Although Davies misinterprets this document in a diocesan context, strictly speaking it illustrates the local impact of metropolitical instructions.

${ }^{58}$ Canterbury Cathedral Archives, Canterbury, Z.4.6, Acta (Canterbury Consistory), 1636-40, fol. 127, my italics. There are similar references at fols. $127 \mathrm{v}$ and 150 . All are ignored by Davies.

${ }^{59}$ Laud, Works (n. 41 above), 4:121, 225, 6:59-60. Instead, Davies relies on an obscure reference during Laud's trial to the "indifferency" of how communion tables should be placed: Davies, p. 231, n. 119; see below, p. 164.

${ }^{60}$ Davies, p. 208 , n. 16, p. 211, nn. 23, 27-28, p. 213, n. 35; Public Record Office, Chancery Lane, SP16/499/42.

${ }^{61}$ Tyacke, Anti-Calvinists (n. 11 above), pp. 199, 209. 
in 1626. If Charles had truly been the moving force behind the altar policy, we would have expected some official sanction like the declaration concerning Sunday sports. What Davies rather grandly calls the "'metropolitical order" has, however, a degree of informality about it that savors more of Laud than the king. Moreover, there is the important fact that these instructions regarding communion tables were issued in the archbishop's name. ${ }^{62}$ Nor will it really do to shift responsibility onto other clerics-in particular the overzealous Matthew Wren, who is portrayed by Davies as the true heir of Andrewes. Laud too was a disciple of Andrewes and modeled his own religious practices on him. ${ }^{63}$ Finally, in the "history" of his troubles and trial, Laud made no attempt to claim à la Davies that he had pursued a different altar policy to that of his master King Charles-an obvious defense, were it true.

The two wings of the revisionist alliance come together most clearly in Kevin Sharpe's massive book-The Personal Rule of Charles I. Although published the same year as White and Davies, Sharpe has been able to take account of their findings prior to publication and finds them jointly to have produced "a full and persuasive new account." But Sharpe is his own man; the conclusions which he has reached as regards the religious development of the 1630s are "based on my own research." ${ }^{64}$ We would be premature to deliver a final verdict on Sharpe's book as a whole. Time will tell how far it comes to look like some great beached leviathan, stranded by the receding tides of revisionism. For present purposes, however, there are two key chapters in this near thousand-page excursus. The first, chapter 6, treats the "Reformation of the Church" under Charles I and Laud. In it the king is portrayed as being motivated by a psychologically based obsession with "order," and Archbishop Laud as the "executor rather than deviser of royal policy." Sharpe correctly points out that on a number of occasions the archbishop denied being an Arminian. Yet Laud did not say what he meant by the term. The present writer has never claimed that, to quote Bernard, Laud or Richard Montagu were Arminians "in the strict sense of someone influ-

\footnotetext{
${ }^{62}$ Davies (n. 46 above), p. 218. It should be pointed out here that the earliest surviving version of the so-called metropolitical order dates from June 1635 and was issued for Gloucester diocese. This says nothing about where communicants should receive, which Davies claims was an essential component. Gloucestershire Record Office, Gloucester, GDR189, fols. 8v-9. I owe this reference to Kenneth Fincham.

${ }^{63}$ Davies, pp. 215-16; Laud, Works, 4:203, 210, 247.

${ }^{64}$ K. Sharpe, The Personal Rule of Charles I (New Haven, Conn., 1992), p. 275, n. 1 .
} 
enced by Arminius." When applied in an English context, the description usually refers to a similarity of doctrine. Nevertheless, Sharpe declines to discuss the evidence for Laud's anti-Calvinist views. ${ }^{65} \mathrm{Sim}-$ ilarly, in a section revealingly entitled "Theological Wrangles," instead of examining the published teaching of Montagu, he provides a pastiche derived from the apologia written by Francis White for having licensed Appello Caesarem. White did indeed shelter behind quotations culled from the sublapsarian Calvinist Robert Abbot and the Suffrage of the British delegation to Dort, but their rehearsal by Sharpe is no substitute for an analysis of Appello Caesarem itself. As regards the York House Conference, we are simply told that "the attempt to prove that Montagu was unorthodox on the subject of predestination failed." Sharpe concludes this section with the baffling statement that "the religion of most protestants, as we shall see, had very little to do with quarrels about supralapsarianism." Four pages earlier he defines "supralapsarianism" as "the doctrine that election and damnation predated the fall." ${ }^{\prime 66}$ But no one has seriously suggested that supralapsarian Calvinism was the doctrine at issue in the early seventeenthcentury controversy about Arminianism.

While the references by Sharpe to the predestinarian dispute suggest a certain lack of comprehension on his part, he manages to produce an unmitigated muddle over the subject of ceremoniesspecifically with reference to "bowing," whether at the name of Jesus or toward the altar. The distinction matters a great deal, because the former was a canonical requirement and the latter not. His discussion here gets off to a particularly bad start from which it never recovers. According to Sharpe, Laud in 1631 opposed the publication of a "defence of bowing to the altar." In fact this book, by William Page, was A Treatise or Justification of Bowing at the Name of Jesus; it was Archbishop Abbot who opposed publication, while Laud encouraged it. Sharpe subsequently fails to distinguish between the different types of bowing, although Laud advocated both. ${ }^{67}$ Turning to the "Altar Controversies," Sharpe misses the point that the dispute centered on where the communion table should generally stand in parish churches. Thus the metropolitical visitation articles of Laud do not conflict with the archbishop's parallel claim that under the terms of the Elizabethan injunctions the communion table should be set "altarwise"; they

${ }^{65}$ Sharpe, pp. 279, 285-87; Tyacke, Anti-Calvinists, pp. x-xi, 266-70; Tyacke, "Archbishop Laud" (n. 42 above), pp. 59-60.

${ }^{66}$ Sharpe, pp. 293-94, 296-97, 300; see above, p. 154.

${ }^{67}$ Sharpe, pp. 287, 328-32; Laud, Works (n. 41 above), 5:39-40, 205-7. 
merely left open the possibility that it might be moved at the time of administering communion. In practice, however, there is scant evidence that Laud favored any such peripatetic principle. We also know that from at least the summer of 1635 Laud's vicar-general was instructing parish authorities to place their communion tables altarwise. Sharpe also appears to confuse "indifferency" with freedom of choice. ${ }^{68}$ Laud did not mean the latter when he described the siting of communion tables as being a matter of indifference, and his position was emphatically not the same as Bishop Williams. Nevertheless, Sharpe claims that the argument of Williams in The Holy Table: Name and Thing "was close to Laud's own practice." In fact, Williams recommended an east-west as opposed to a north-south (altarwise) placing of parish communion tables. ${ }^{69}$

Like Davies, Sharpe seeks to portray the Calvinist Bishop Davenant as more "Laudian" than Laud-but adds a further dimension by introducing the case of Henry Sherfield, who was prosecuted in Star Chamber for breaking an allegedly idolatrous church window at St. Edmund's, Salisbury. According to Sharpe, Davenant was the prime instigator of this prosecution. "Sherfield had challenged the bishop's authority - an authority which the Calvinist Davenant was as determined to preserve as Laud." Sharpe, however, suppresses (the word does not seem too strong) a key set of documents among the State Papers concerning the role of the dean of Salisbury, Edmund Mason. These reveal Mason, in March 1633, pressing for a much harsher form of recantation by the puritan Sherfield than that sanctioned by Davenant and expressing grave doubts about the bishop's own firmness against "the faction that now domineers in his diocese." Davenant "in this, as in all other busynesses of ecclesiastical defence, casts backward and retyres himselfe into caution and sylence." Mason wanted Sherfield to confess to having cast a "reproch and scandall" on "the blessed reformation of true religion from superstitious popery, together with the whole government both of state and church in England." The dean also forwarded to Secretary Windebank a petition from Davenant's chancellor, who was seeking to recover his costs for prosecuting Sherfield in Star Chamber, and similarly invoked the support of Laud. ${ }^{70}$ Not one word of this is revealed by Sharpe, despite

${ }^{68}$ Sharpe, pp. 333-35; Laud, Works, 5:421, 6:60; see n. 62 above; for the doctrine of religious things "indifferent"-i.e., not ordained by God, but which can still be legally binding-see B. J. Verkamp, The Indifferent Mean: Adiaphorism in the English Reformation to 1554 (Athens, Ohio, 1977), esp. chap. 7.

${ }^{69}$ Sharpe, pp. 334, 338; Tyacke, Anti-Calvinists (n. 11 above), p. 209.

${ }^{70}$ Sharpe, pp. 345-48; Public Record Office, Chancery Lane, SP16/233/88. 
entitling his account a "Case Study in Complexities." Davenant indeed would appear to have been caught in the cross-fire between a group of avant-garde conformists based on Salisbury cathedral close and the city puritans. Moreover, both Laud and Neile used their speeches against Sherfield, in Star Chamber, to defend religious imagery in churches-especially pictures of Christ. ${ }^{71}$ Again, this goes unremarked by Sharpe.

"Puritanism and Opposition" is the subject of Sharpe's chapter 12. He rightly remarks that the "radical potential of puritanism" has been "wrongly downplayed in recent years" by many historians but does not venture far in redressing the balance-presumably for fear of bringing his own revisionist edifice tumbling down. ${ }^{72}$ Puritans such as John Pym still appear out of virtually nowhere in 1640 . Nor is any real explanation offered as to why, for instance, the former clerk of the closet to Prince Charles (Henry Burton) or someone on visiting terms at Lambeth Palace under Archbishop Abbot (William Prynne) were driven to puritan extremism during the 1630s. In the account which is offered, however, the term "separatist" is used with reckless abandon. Among those so described are the perpetual curate of St. Mary, Aldermanbury, Dr. John Stoughton, and the eminently respectable Sir Humphrey Lynde, the latter on the basis of a catholic satire which Sharpe culpably assumes to be a genuine work by Lynde. ${ }^{73}$ At the same time, the only real novelty which Sharpe sees in the religious situation under Charles I is the stricter enforcement of conformity to the existing rules. The numbers of puritans, he suggests, were "small" and "radical puritans were a tiny sect." A mixture of governmental mistakes and sheer bad luck from 1637 onward was what, in his view, "began to change the climate, to radicalize the moderates and to bring a measure of public sympathy to their cause." According to Sharpe, the same goes for secular grievances such as Ship Money. ${ }^{74}$ Enormous weight, therefore, is put on the Scottish rebellion and its political consequences. Sharpe in fact wishes to elevate short-termism to an un-

${ }^{71}$ T. B. Howell and T. J. Howell, eds., A Complete Collection of State Trials, 34 vols. (London, 1816-28), 3:548-53, 557-59.

${ }_{72}$ Sharpe, pp. 694, 731-32. For an attempt to redress the balance, see N. Tyacke, "The 'Rise of Puritanism' and the Legalising of Dissent, 1571-1719," in From Persecution to Toleration: The Glorious Revolution and Religion in England, ed. O. P. Grell, J. I. Israel, and N. Tyacke (Oxford, 1991), pp. 17-28; and N. Tyacke, The Fortunes of English Puritanism, 1603-1640, Dr. Williams's Library Lecture (London, 1990).

${ }_{73}^{73}$ Sharpe, pp. 734, 740; [J. Floyd?], A Letter of Sir Humfrey Linde [St. Omer] (1634). Daniel Featley preached Lynde's funeral sermon in 1638, while Stoughton died in post during 1639 .

${ }^{74}$ Sharpe, pp. 292, 729-30, 757. 
precedented height among revisionist accounts of the origins of the English Civil War.

The present writer has argued that "religion was a major contributory cause" of the armed conflict which broke out in 1642. But to say this does not, as Julian Davies assumes, preclude other causes. Thus I have never myself jibbed at the term "absolutist", to describe certain tendencies in early Stuart government. It is true that stress on the role of Arminianism has had the unfortunate consequence of distracting attention from puritanism - something which my own recent work has endeavored to correct. ${ }^{75}$ The important religious changes during the reign of Charles I, which served further to alienate puritans, also need to be seen in a much longer perspective. What resurfaced in the early seventeenth century under the guise of Arminianism clearly had a prehistory in the Elizabethan struggle for dominance between Calvinists and Lutherans. Nevertheless, it was the fusion of religious and secular discontents that was always potentially the most dangerous. Although there are traces of this under Elizabeth, the external threat from Spain was a limiting factor on any protestant opposition. Peace and the failure of financial reform after the accession of James I, however, led to a deteriorating political situation. The pursuit of a Spanish alliance abroad produced allegations of popery at home, and the financial straits of the government led increasingly to the adoption of arguably unconstitutional solutions. By the end of the 1620 s a particularly virulent form of popish plot theory had come into existence, which combined secular and religious grievances in an all-embracing explanation. This situation is all the more striking because England was by now fighting both Spain and France, the two major catholic powers. Here continued royal support for the anti-Calvinist faction within the English Church looks to have been the key element, yet clearly much more was involved than simply the theology of grace. In this context we might well adapt Davies's notion of a "recatholicization" of the English Church. Nothing indeed appeared sacrosanct. Even the cardinal doctrine of justification by faith alone was to come under attack, while the idea of what constituted idolatry was more and more restricted and communion tables were turned back into altars. At the same time, the secularization of church property, consequent upon the Reformation, seemed increasingly at risk. The net effect was that by 1640 the earlier charge of Arminianism had escalated into the much more damaging one of popery. ${ }^{76}$

75 Tyacke, Anti-Calvinists, pp. 159, 245; Davies (n. 46 above), pp. 1-4, 49-50, 313-18; see n. 72 above.

${ }^{76}$ Tyacke, Anti-Calvinists, pp. 54, 139, 157-59, 192-94, 198-216; D. Hoyle, “A 
How close the Caroline government ever came to solving its financial problems remains unclear. ${ }^{77}$ Yet the need to suppress the Scottish rebellion rapidly exhausted existing funds and, hence, the recourse to Parliament. Undoubtedly it was the Scottish crisis that enabled the domestic opponents of royal policy to make themselves heard. Similarly the point is well made that some two years elapsed between the meeting of the Long Parliament and the actual outbreak of fighting. That granted, however, we must also take into account certain prior changes. The origins of the emerging opposition program in 1640-42 are traceable not only to the 1620 s but in some respects back to the reign of Queen Elizabeth. Neither the monarchy nor the English Church had stood still during the interim, any more than had the puritans and other critics. It is less a question of apportioning blame for what happened-a rather sterile task at the best of times-than of trying to discern the long-term pattern of developments. In this connection the idea of an unchanging Anglican via media remains deeply unhelpful, as does that of a flourishing Stuart regime brought down by a Scottish bolt from the blue.

Commons Investigation of Arminianism and Popery in Cambridge on the Eve of the Civil War," Historical Journal 29 (1986): 419-25; C. Hill, Economic Problems of the Church: From Archbishop Whitgift to the Long Parliament (Oxford, 1956), esp. chap. 14.

${ }^{77}$ P. K. O'Brien and P. A. Hunt, "The Rise of a Fiscal State in England, 14851815," Historical Research 66 (1993): 151, 154. 